\title{
KETERAMPILAN BERPIKIR KRITIS SISWA PADA MATERI LAJU REAKSI DI KELAS XI MIA SMA NEGERI 1 MANYAR
}

\author{
Pradita Rahmadhani ${ }^{1}$, Dian Novita ${ }^{2 *}$ \\ 1,2 Jurusan Kimia FMIPA Universitas Negeri Surabaya
}

\begin{abstract}
Abstrak - Penelitian ini bertujuan mendeskripsikan keterampilan berpikir kritis siswa pada materi Laju Reaksi yang didukung dengan aktivitas siswa selama pembelajaran. Pada pembelajaran ini dilakukan penerapan model pembelajaran Guided Inquiry. Penelitian ini menggunakan metode one group pretest posttest. Dalam penelitian ini dapat disimpulkan bahwa setelah pembelajaran, keterampilan berpikir kritis siswa tuntas pada semua komponen yang diujikan, yaitu interpretasi, inferensi, analisis dan eksplanasi, dengan rata-rata nilai berturut-turut sebesar 97,14; 100; 54,29 dan 94,28. Aktivitas siswa pada dua pertemuan menunjukkan aktivitas dominan sebesar 97,34\% pada pertemuan 1 dan 98,55\% pada pertemuan 2 yang mendukung pembelajaran yang melatihkan keterampilan berpikir kritis.
\end{abstract}

Kata kunci: keterampilan berpikir kritis, aktivitas siswa, laju reaksi

\begin{abstract}
This study aims to describe students' critical thinking skills on Reaction Rate material supported by student activity during learning. In this study, the implementation of Guided Inquiry instruction model. This research uses one group pretest posttest method. In this study, it can be concluded that after learning, students' critical thinking skill is complete on all components tested, that is interpretation, inference, analysis and explanation, with average value of 97,14 respectively; 100; 54.29 and 94.28. Student activity at two meetings showed a dominant activity of $97.34 \%$ at 1 st and $98.55 \%$ at 2 nd meeting in favor of learning that trained critical thinking skills.
\end{abstract}

Keywords: critical thinking skills, student's activity, reaction rate

\section{PENDAHULUAN}

Depdikbud 2013 menyatakan bahwa mata pelajaran Kimia dalam kurikulum 2013 merupakan salah satu mata pelajaran peminatan Matematika dan Ilmu Pengetahuan Alam. Kimia berkaitan dengan cara mencari tahu tentang fenomena alam secara sistematik, sehingga proses pembelajarannya bukan hanya sekedar penguasaan kumpulan pengetahun yang berupa faktafakta, konsep-konsep, atau prinsip-prinsip saja tetapi juga merupakan proses penemuan. Setelah mempelajari kimia siswa diharapkan memperoleh pengalaman dalam menerapkan metode ilmiah, melalui percobaan dan eksperimen. Hal ini sejalan dengan Peraturan Menteri No. 23 tahun 2006 tentang tujuan Standar Kompetensi Lulusan Satuan Pendidikan (SKL-SP) untuk SMA yaitu harus menujukkan kemampuan berpikir logis, kritis, kreatif dan inovatif dalam pengambilan keputusan. Berpikir kritis disebutkan sebagai salah satu kebutuhan kompetensi masa depan yang perlu dimiliki oleh siswa.

Kemampuan berpikir kritis merupakan cara berpikir reflektif dan beralasan yang difokuskan pada pengambilan keputusan untuk memecahkan masalah. berpikir kritis dibagi menjadi tiga tahap dan ada enam kecakapan utama yang terlibat. Kecakapan tersebut adalah (i) interpretasi yakni kemampuan untuk mengubah informasi yang disajikan dari satu bentuk ke bentuk yang lain, (ii) analisis adalah mengidentifikasi hubungan-hubungan inferensial yang dimaksud dan aktual diantara pernyataan-pernyataan, pertanyaan-pertanyaan, konsep-konsep, deskripsi-deskripsi atau 
bentuk-bentuk mengekspresikan kepercayaan-kepercayaan, penilaian, pengalaman-pengalaman, alasan-alasan, informasi atau opini-opini, (iii) evaluasi berarti menaksir kredibilitas pernyataanpernyataan atau representasi-representasi yang merupakan laporan-laporan atau deskripsideskripsi dari persepsi, pengalaman, situasi, penilaian, kepercayaan atau opini seseorang, dan menaksir kekuatan logis dari hubungan-hubungan inferensial atau dimaksud diantara pernyataanpernyataan, deskripsi-deskripsi, pertanyaan-pertanyaan, atau bentuk-bentuk representasi lainnya, (iv) inferensi berarti mengidentifikasi dan memperoleh unsur-unsur yang diperlukan untuk membuat kesimpulan-kesimpulan yang masuk akal; membuat dugaan-dugaan atau hipotesis; mempertimbangkan informasi yang relevan dan menyimpulkan konsekuensi-konsekuensi dari data, situasi-situasi, pertanyaan-pertanyaan, atau bentuk representasi lainnya, (v) eksplanasi berarti mampu menyatakan hasil-hasil dari penalaran seseorang menjustifikasi penalaran tersebut dari sisi pertimbangan-pertimbangan evidensial, konseptual, metodologis dan kontekstual di mana hasilhasil seseorang tersebut berdasar, dan mempresentasikan penalaran seseorang dalam bentuk argumen-argumen yang kuat dan (vi) regulasi diri berarti secara sadar diri memantau kegiatankegiatan kognitif seseorang, unsur-unsur yang digunakan dalam kegiatan-kegiatan tersebut, dan hasil-hasil yang diperoleh terutama dengan menerapkan kecakapan-kecakapan di dalam analisis dan evaluasi untuk penilaian-penilaian inferensialnya sendiri dengan memandang pada pertanyaan, konfirmasi, validitas atau mengkoreksi baik penalarannya atau hasil-hasilnya (Filsaime, 2008).

Keterampilan berpikir kritis sebagai berikut: (1) pemikiran mendalam mengenai permasalahan sekitar, (2) alasan realistik tentang pengetahuan, (3) keterampilan penerapan metode (Carisma,2017). Salah satu pembelajaran yang dapat membantu siswa untuk mengembangkan kemampuan berpikir kritisnya adalah pembelajaran inkuiri terbimbing (Guided Inquiry). Berdasarkan hasil wawancara dengan guru kelas, beliau menyatakan bahwa pembelajaran berbasis inkuiri belum pernah diterapkan sebelumnya dengan alasan terkendala waktu.

Proses inkuiri dapat membantu menemukan pengetahuan baru (Asni, 2015). Pembelajaran inkuiri dapat mengembangkan cara berpikir ilmiah yang menempatkan siswa sebagai pembelajar dalam memecahkan permasalahan dan memperoleh pengetahuan yang bersifat penyelidikan sehingga dapat memahami konsep-konsep sains. Selain itu, kekurangan pembelajaran inkuiri adalah suasana kelas menjadi ramai dan kegiatan diskusi belum maksimal. Oleh sebab itu, perlu adanya suatu integrasi pembelajaran inkuiri dengan pembelajaran lainnya agar lebih efektif lagi dalam mengoptimalkan keterampilan berpikir kritis siswa. Dalam tahap awal hanya dilatihkan beberapa komponen sebelum menuju ke tingkatan yang lebih tinggi. Dalam hal ini perlu adanya bantuan untuk mengatasi permasalahan di atas secara akurat.

\section{METODE}

Jenis penelitian ini merupakan penelitian semu eksperimen tidak sebenarnya dengan metode kuantitatif. Desain penelitian menggunakan one group pretest posttest.

$$
\mathrm{O}_{1}-\mathrm{X}-\mathrm{O}_{2}
$$

\section{Keterangan:}

O1 : tes tanpa penerapan model pembelajaran Guided Inquiry

$\mathrm{X} \quad$ : diperlakukan penerapan model pembelajaran Guided Inquiry

O2 : tes setelah diperlakukan penerapan model pembelajaran Guided Inquiry

\section{Keterampilan Berpikir Kritis}


Keterampilan berpikir kritis tersebut diukur berdasarkan kemampuan siswa dalam mengerjakan soal tes tentang permasalahan dan cara penyelesaiannya. Untuk menilai keterampilan berpikir kritis dilakukan metode pretest berpikir kritis sebelum diberi perlakuan pembelajaran dengan inkuiri dan posttest hasil berpikir kritis yang diberikan di akhir setelah diberi perlakuan pembelajaran inkuiri. Jenis tes yang diberikan adalah essay.

Analisis keterampilan berpikir kritis melalui perhitungan nilai $\langle\mathrm{g}\rangle$ untuk mengetahui seberapa besar perbedaan antara nilai pretest dan posttest.

$$
<g>=\frac{\text { nilai posttest }- \text { nilai pretest }}{\text { nilai maksimum-nilai pretest }}
$$

(Riduwan, 2011)

Selanjutnya angka yang didapatkan dikonversikan dengan kategori seperti pada tabel 1.

Tabel 1 Kriteria Gain Skor

\begin{tabular}{ll}
\hline Nilai $\langle\mathrm{g}>$ & Kriteria \\
\hline$\langle\mathrm{g}>\geq 0,7$ & Tinggi \\
\hline $0,7><\mathrm{g}>\geq 0,3$ & Sedang \\
\hline$<\mathrm{g}><0,3$ & Rendah \\
\hline
\end{tabular}

\section{Aktivitas Siswa}

(Hake, 1998)

Aktivitas siswa selama kegiatan pembelajaran dianalisis secara deskritif kuantitatif berdasarkan rata-rata hasil pengamatan dari 3 pengamat. Data tersebut kemudian dianalisis dengan menghitung persentase kegiatan yang dilakukan siswa selama pembelajaran menggunakan model pembelajaran Guided Inquiry, dengan rumus sebagai berikut:

\% Aktivitas Siswa $=\frac{\sum \text { Frekuensi aktivitas siswa yang muncul }}{\sum \text { Frekuensi aktivitas keseluruhan }} \times 100 \%$

(Arifin, 2011)

Aktivitas siswa yang diamati adalah sebagai berikut: memperhatikan penjelasan guru; membaca fenomena di LKS; merumuskan masalah dan mencatatnya; mengajukan hipotesis dan mencatatnya; mengajukan hipotesis dan mencatatnya; menentukan variabel yang sesuai; bekerjasama dengan kelompok dalam melakukan percobaan; melakukan diskusi dengan kelompok; menganalisis data; mengerjakan soal evaluasi; menarik kesimpulan; mempresentasikan hasil percobaan dan melakukan aktivitas tidak relevan (seperti: bermain handphone, mengganggu teman lain, membuat gaduh, dll).

\section{HASIL DAN PEMBAHASAN}

Pada bagian ini akan disajikan hasil penelitian dan pembahasan penelitian yang telah diperoleh selama pelaksanaan penelitian di SMA Negeri 1 Manyar Gresik. Pemilihan kelas ditentukan secara acak oleh guru mata pelajaran kimia dan hanya menggunakan satu kelas untuk dijadikan subjek penelitian tanpa adanya kelas kontrol. Pengambilan data dilaksanakan selama 2 kali pertemuan dengan hari yang berbeda yaitu pada tanggal 31 Oktober dan 2 November 2017 di SMA Negeri 1 Manyar Gresik pada kelas XI dengan jumlah siswa 35 orang.

\section{Keterampilan Berpikir Kritis}

Keterampilan berpikir kritis siswa diukur melalui tes yang mengacu pada komponen berpikir kritis. Tes yang dilakukan berupa pretest dan posttest, dimana pretest dilakukan sebelum pembelajaran tanpa penerapan model pembelajaran Guided Inquiry dan posttest dilakukan setelah diberikan penerapan model pembelajaran Guided Inquiry. Soal yang digunakan untuk 
mengetahui peningkatan keterampilan berpikir kritis siswa adalah berupa soal uraian, dimana soal tersebut telah mencakup 4 komponen keterampilan berpikir kritis dari 6 komponen keterampilan berpikir kirits yang dilatihkan menurut Facione (dalam Filsaime, 2008). Komponen keterampilan berpikir kritis yang dilatihkan dan disajikan dalam bentuk soal pretest dan posttest yakni interpretasi, inferensi, analisis dan eksplanasi. Proses melatihkan empat komponen keterampilan berpikir kritis di atas dilakukan dengan kegiatan mengisi pertanyaan yang terdapat pada LKS yang berupa soal uraian dengan 4 komponen keterampilan berpikir kritis.

Berikut akan disajikan data hasil analisis hasil keterampilan berpikir kritis pretest hingga posttest ditinjau dari ketuntasannya. Siswa dapat dikatakan berhasil apabila hasil keterampilan berpikir kritis mendapatkan skor $\geq 2,66$ sesuai dengan yang diatur pada kurikulum 2013 dengan predikat B dimana nilai tersebut pula sesuai dengan kriteria ketuntasan minimal (KKM) di SMA Negeri 1 Manyar Gresik. Berikut disajikan hasil pretest dan posttest keterampilan berpikir kritis pada Tabel 2.

Tabel 2. Nilai Pretest dan Posttest Keterampilan Berpikir Kritis

\begin{tabular}{|c|c|c|c|c|c|c|c|c|c|c|}
\hline \multirow{2}{*}{ Siswa } & \multicolumn{4}{|c|}{ Pretest } & \multirow{2}{*}{$\begin{array}{l}\text { Rerata } \\
\text { Pretest }\end{array}$} & \multicolumn{4}{|c|}{ Posttest } & \multirow{2}{*}{$\begin{array}{l}\text { Rerata } \\
\text { Posttest }\end{array}$} \\
\hline & Interpretasi & Analisis & Inferensi & Eksplanasi & & Interpretasi & Analisis & Inferensi & Eksplanasi & \\
\hline 1 & 0,33 & 0 & 0 & 0 & 0,08 & 3,66 & 2 & 4 & 4 & 3,42 \\
\hline 2 & 0,83 & 1 & 0 & 0 & 0,46 & 2,495 & 2,5 & 3,5 & 3 & 2,87 \\
\hline 3 & 0,665 & 0 & 3,5 & 0 & 1,04 & 4 & 3 & 4 & 4 & 3,75 \\
\hline 4 & 1,83 & 0 & 0 & 0 & 0,46 & 3 & 2 & 4 & 3 & 3,00 \\
\hline 5 & 1,665 & 0 & 0 & 0 & 0,42 & 3,665 & 3 & 4 & 4 & 3,67 \\
\hline 6 & 1,165 & 0,5 & 0 & 0 & 0,42 & 3,83 & 3 & 4 & 4 & 3,71 \\
\hline 7 & 0,33 & 0 & 0 & 0 & 0,08 & 4 & 3 & 4 & 2,5 & 3,38 \\
\hline 8 & 0,165 & 0 & 0 & 0 & 0,04 & 4 & 4 & 4 & 4 & 4,00 \\
\hline 9 & 0,665 & 0 & 0 & 0 & 0,17 & 3,83 & 3 & 4 & 4 & 3,71 \\
\hline 10 & 1,33 & 1,5 & 1,5 & 1,5 & 1,46 & 4 & 4 & 4 & 4 & 4,00 \\
\hline 11 & 0,33 & 0 & 0 & 0 & 0,08 & 4 & 3,5 & 4 & 4 & 3,88 \\
\hline 12 & 2,33 & 0 & 0 & 0 & 0,58 & 3,33 & 3 & 4 & 3,5 & 3,46 \\
\hline 13 & 1 & 0 & 0 & 0 & 0,25 & 4 & 2 & 4 & 4 & 3,50 \\
\hline 14 & 1 & 0 & 0 & 0 & 0,25 & 3,83 & 2,5 & 4 & 3,5 & 3,46 \\
\hline 15 & 0,5 & 0 & 0 & 0 & 0,13 & 4 & 3,5 & 4 & 3,5 & 3,75 \\
\hline 16 & 1 & 0 & 0 & 0 & 0,25 & 4 & 3 & 4 & 3,5 & 3,63 \\
\hline 17 & 0,33 & 0 & 0,5 & 0 & 0,21 & 3,665 & 2 & 4 & 4 & 3,42 \\
\hline 18 & 1,165 & 1 & 2 & 1 & 1,29 & 3,665 & 3 & 3 & 3,5 & 3,29 \\
\hline 19 & 0,165 & 0 & 0 & 0 & 0,04 & 3,665 & 2 & 3 & 3 & 2,92 \\
\hline 20 & 0,165 & 0,17 & 0 & 0 & 0,08 & 3,665 & 2 & 3 & 3 & 2,92 \\
\hline 21 & 0,5 & 0 & 0 & 0 & 0,13 & 3,83 & 3 & 4 & 3,5 & 3,58 \\
\hline 22 & 0 & 0 & 0 & 0 & 0,00 & 3,665 & 3 & 4 & 3,5 & 3,54 \\
\hline 23 & 1,165 & 0 & 0 & 0 & 0,29 & 4 & 2,5 & 4 & 4 & 3,63 \\
\hline 24 & 0,83 & 0 & 0 & 0 & 0,21 & 4 & 2 & 4 & 4 & 3,50 \\
\hline 25 & 0 & 0 & 0 & 0 & 0,00 & 3,665 & 2,5 & 4 & 4 & 3,54 \\
\hline 26 & 0,33 & 0 & 0 & 0 & 0,08 & 3,165 & 1,5 & 3,5 & 3,5 & 2,92 \\
\hline 27 & 1,995 & 1,5 & 1 & 1 & 1,37 & 4 & 4 & 4 & 3 & 3,75 \\
\hline 28 & 1,33 & 1 & 1,5 & 0 & 0,96 & 4 & 4 & 4 & 4 & 4,00 \\
\hline 29 & 1,165 & 0 & 0 & 0 & 0,29 & 3,665 & 2,5 & 4 & 4 & 3,54 \\
\hline 30 & 0,665 & 0 & 0 & 0 & 0,17 & 4 & 2 & 3,5 & 3 & 3,13 \\
\hline 31 & 1 & 1 & 0 & 0 & 0,50 & 3,5 & 3,5 & 4 & 4 & 3,75 \\
\hline 32 & 0,665 & 1 & 1 & 0,5 & 0,79 & 3,33 & 2 & 4 & 3,5 & 3,21 \\
\hline 33 & 0,165 & 0 & 0 & 0 & 0,04 & 4 & 4 & 4 & 4 & 4,00 \\
\hline 34 & 0,165 & 0 & 0 & 0 & 0,04 & 4 & 2 & 4 & 3,5 & 3,38 \\
\hline 35 & 0,83 & 0 & 0 & 0 & 0,21 & 3,33 & 3 & 4 & 2,5 & 3,21 \\
\hline Total & 0,79 & 0,25 & 0,31 & 0,11 & 0,37 & 3,73 & 2,79 & 3,87 & 3,60 & 3,50 \\
\hline
\end{tabular}




\section{Aktivitas Siswa}

Pengamatan aktivitas siswa memiliki tujuan untuk mengetahui segala aktivitas siswa selama proses pembelajaran menggunakan penerapan Guided Inquiry berlangsung. Pengamatan aktivitas siswa dilakukan oleh 2 orang pengamat, dengan tiap pengamat mengamati 3 kelompok dimana terdapat enam kelompok yang terdiri dari 5 sampai 6 siswa. Tiga kelompok dibuat sebanjar sehingga terdapat dua banjar yang akan diamati. Hal ini agar pengamat mudah untuk mengamati aktivitas siswa sehingga tidak perlu berpindah-pindah. Frekuensi aktivitas siswa yang muncul diamati setiap 3 menit sekali selama kegiatan pembelajaran. Berikut ini hasil pengamatan analisis aktivitas siswa pada pertemuan 1 dan 2 secara ringkas pada tabel 3.

Tabel 3 Data Pengamatan Aktivitas Siswa

\begin{tabular}{|c|c|c|c|}
\hline \multirow{2}{*}{ No } & \multirow{2}{*}{ Aktivitas } & \multicolumn{2}{|c|}{ Persentase Aktivitas Siswa (\%) } \\
\hline & & Pertemuan 1 & Pertemuan 2 \\
\hline 1 & Memperhatikan penjelasan guru & 12,7 & 13,25 \\
\hline 2 & Membaca fenomena di LKS & 7,14 & 7,26 \\
\hline 3 & Merumuskan masalah dan mencatatnya & 5,66 & 10,25 \\
\hline 4 & Mengajukan hipotesis dan mencatatnya & 5,66 & 8,25 \\
\hline 5 & Menentukan variabel yang sesuai & 5,66 & 7,26 \\
\hline 6 & Melakukan percobaan & 19,62 & 28,84 \\
\hline 7 & Menyusun data hasil percobaan ke dalam tabel & 5,66 & 4,25 \\
\hline 8 & Menyusun data hasil percobaan ke dalam grafik & 5,66 & 2,17 \\
\hline 9 & Menganalisis data & 7,02 & 3,27 \\
\hline 10 & Mengerjakan soal aplikasi & 7,02 & 3,27 \\
\hline 11 & Menarik kesimpulan & 4,07 & 3,27 \\
\hline 12 & Mempresentasikan hasil percobaan & 11,47 & 7,26 \\
\hline 13 & $\begin{array}{l}\text { Melakukan aktivitas tidak relevan (seperti: bermain } \\
\text { bandphone, mengganggu teman, membuat gaduh, dll) }\end{array}$ & 2,66 & 1,45 \\
\hline & Total & 100 & 100 \\
\hline
\end{tabular}

Pada tabel 3 dapat dilihat beberapa aktivitas yang diamati untuk mendukung hasil pembelajaran yang melatihkan keterampilan berpikir kritis siswa pada tiap pertemuannya.

\section{Komponen Interpretasi}

Pada komponen ini dilatihkan keterampilan berpikir kritis pada komponen interpretasi yang diukur dengan 3 soal uraian dimana soal tersebut membahas tentang merumuskan masalah, merumuskan hipotesis dan menentukan variabel sesuai dengan fenomena yang diberikan. Pengertian interpretasi menurut Facione (dalam Filsaime, 2008) yaitu kemampuan untuk mengubah informasi yang disajikan dari satu bentuk ke bentuk yang lain. Pada komponen interpretasi, jawaban pretes yang dituliskan masih kurang tepat sehingga dalam komponen interpretasi masih dikatakan kurang. Dapat dilihat pada rata-rata hasil komponen interpretasi yakni sebesar 0,79 pada pretes dan hampir 100\% siswa tidak memenuhi ketuntasan KKM di SMAN 1 Manyar. Berikut disajikan hasil pretes salah satu subjek pada gambar 1. 


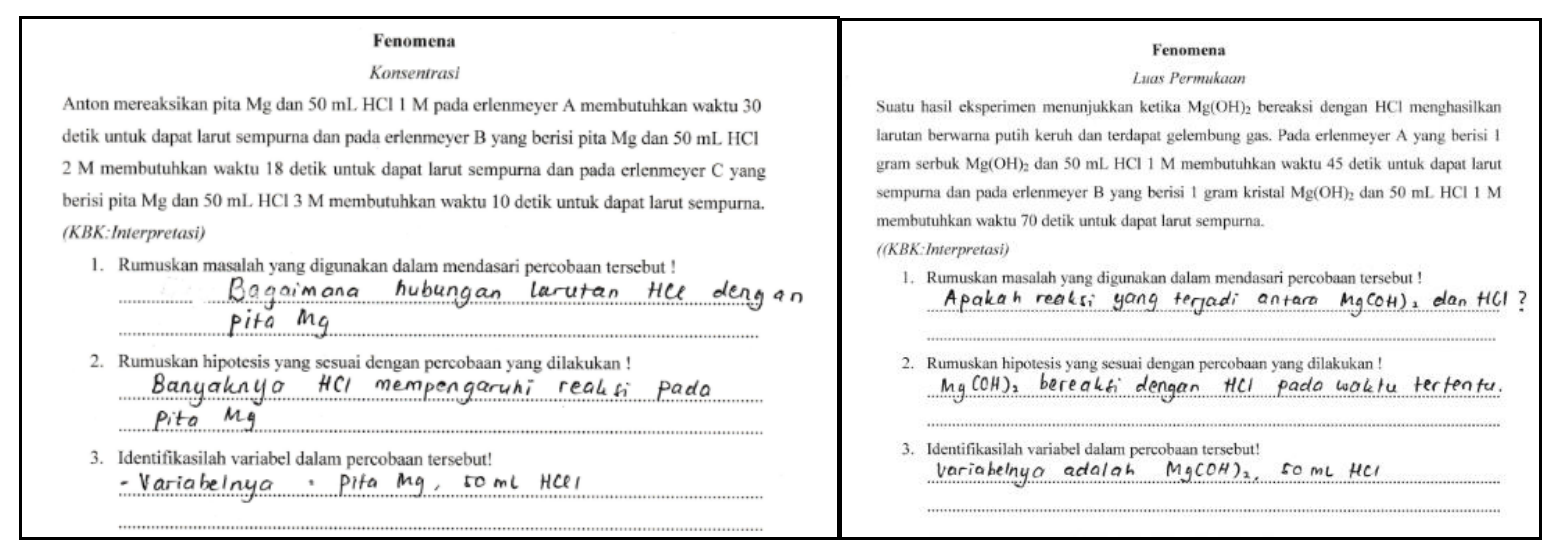

Gambar 1. Hasil Pretest salah satu subjek pada Komponen Interpretasi

Pada gambar 1, jawaban siswa masih kurang tepat dan tidak sesuai dengan kisi-kisi jawaban. Pada nomor 1 jawaban yang di kemukakan masih kurang tepat pada kata "larutan" dan kurang lengkap pada fenomena luas permukaan. Pada nomor 2 fenomena konsentrasi tidak ada keterangan jelas mengenai pengaruh yang terjadi begitu pula pada fenomena luas permukaan. Pada nomor 3 variabel yang di kemukakan tidak lengkap pada kedua fenomena.

Pada posttest terjadi peningkatan rata-rata nilai yang diperoleh siswa, jika pada pretest rata-rata nilai siswa yang diperoleh hanya 0,79 dan $100 \%$ siswa tidak tuntas, maka pada posttest sebesar $97,14 \%$ siswa tuntas dengan nilai rata-rata sebesar 3,73. Hal tersebut dapat dikatakan bahwa pembelajaran menggunakan model pembelajaran guided inquiry mampu melatihkan komponen interpretasi. Pada komponen interpretasi, secara umum jawaban yang dituliskan siswa benar dan tepat, yaitu telah mampu mengidentifikasi variabel manipulasi dan respon serta mampu membuat suatu rumusan masalah yang menghubungkan kedua variabel tersebut. Dari nilai pretest dan posttest yang didapat keterampilan berpikir kritis siswa pada komponen interpretasi efektif dilatihkan dan mengalami peningkatan nilai yang sangat baik.

Hal ini didukung dari data aktivitas 2 pada tabel 3, yaitu membaca fenomena di LKS dengan persentase waktu sebesar 7,14\% pada pertemuan pertama dan 7,26\% pada pertemuan kedua. Fenomena yang terdapat di LKS yakni fenomena faktor-faktor yang mempengaruhi laju reaksi dalam kehidupan sehari-hari. Aktivitas ini melatihkan keterampilan berpikir kritis komponen interpretasi yakni kemampuan untuk mengubah informasi yang disajikan dari satu bentuk ke bentuk yang lain (Filsaime, 2008). Pada pertemuan kedua waktu dominan aktivitas yang terjadi semakin besar dikarenakan format LKS yang disusun sedemikian rupa sehingga siswa harus mampu melakukan interpretasi berdasarkan bantuan LKS yang telah dikerjakan di pertemuan 1. Dalam menyelesaikan masalah yang diberikan siswa perlu mengingat kembali atau melihat kembali pekerjaannya pada pertemuan sebelumnya.

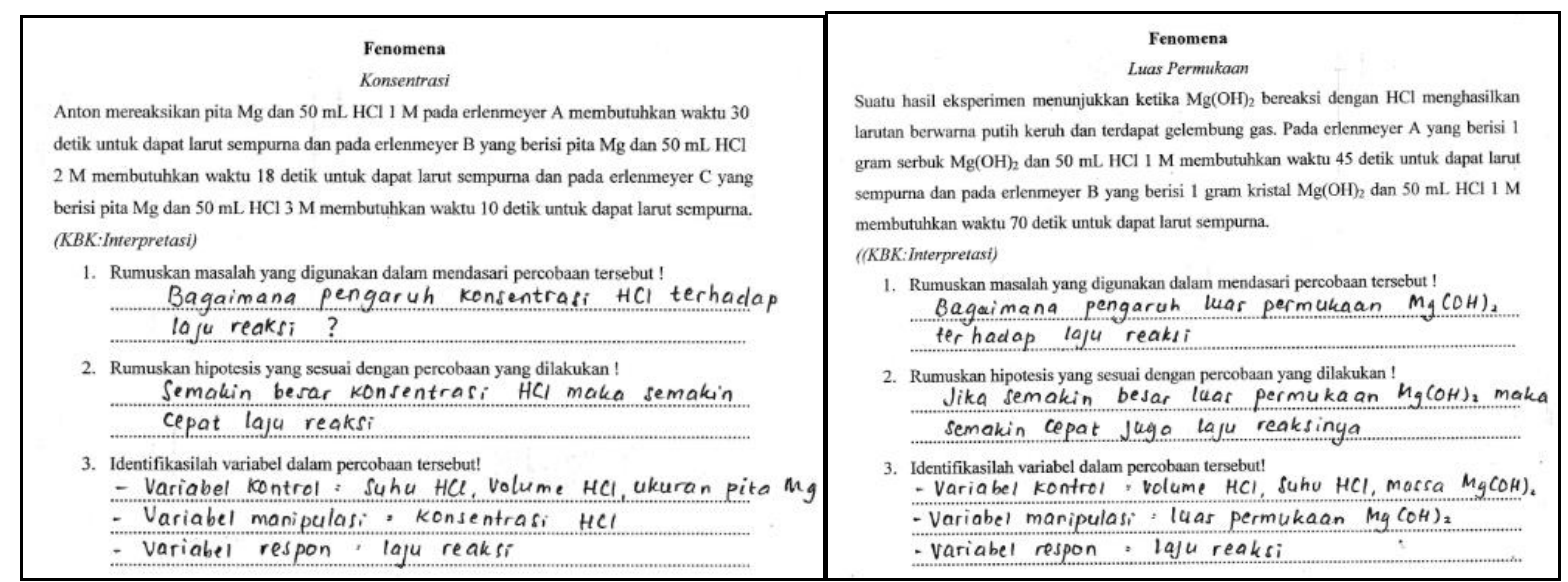

Gambar 2. Hasil Posttest salah satu subjek pada Komponen Interpretasi 
Pada gambar 2, hasil posttest yang dikemukakan sudah semakin baik daripada pretest. Terlihat pada nomor 1,2 dan 3 kedua fenomena menunjukkan jawaban yang sudah tepat sesuai dengan kisi-kisi soal. Namun pada salah satu subjek masih memperoleh nilai tidak tuntas pada posttest. Hal ini disebabkan pada jawaban yang telah dikemukakan oleh subjek tersebut kurang tepat dan tidak memenuhi indikator yang telah ditentukan. Jawaban yang dikemukakan subjek pada pretes dikemukakan kembali pada saat posttest sehingga jawaban tersebut tidak memperoleh nilai maksimum. Selain itu faktor keterbatasan pelaksanaan pembelajaran yang tidak sesuai dengan rencana awal menjadi salah satu kendala pada penyampaian materi.

\section{Komponen Analisis}

Pengertian analisis menurut Facione (dalam Filsaime, 2008) yaitu mengidentifikasi hubunganhubungan inferensial yang dimaksud dan aktual diantara pernyataan-pernyataan, pertanyaanpertanyaan, konsep-konsep, deskripsi-deskripsi atau bentuk-bentuk mengekspresikan kepercayaan-kepercayaan, penilaian, pengalaman-pengalaman, alasan-alasan, informasi atau opiniopini. Keterampilan berpikir kritis pada komponen analisis diukur sebanyak 1 soal uraian dimana soal tersebut membahas tentang analisis bagaimana percobaan tersebut terjadi. Pada komponen analisis diperoleh nilai rata-rata hasil pretest sebesar 0,25 atau hampir 100\% nilai siswa tidak tuntas. Siswa cenderung tidak dapat menjawab soal yang telah diberikan. Berikut disajikan hasil pretest salah satu subjek pada gambar 3 .

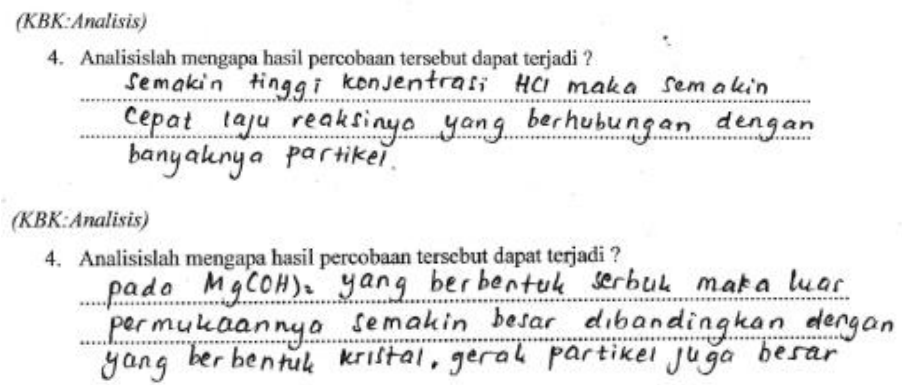

Gambar 3. Hasil Pretest salah satu subjek pada Komponen Analisis

Pada gambar 3, hasil pretest menunjukkan jawaban yang dikemukakan tidak sesuai dengan kisi-kisi soal terlihat pada fenomena konsentrasi terdapat kata "banyaknya partikel" yang tidak di perlukan. Sedangkan pada fenomena luas permukaan kata "berbentuk kristal" kurang tepat. Ketika pembelajaran berlangsung siswa diajarkan dan dilatihkan untuk menjawab soal komponen analisis melalui LKS dan akhirnya pada saat menjawab soal posttest siswa menujukkan peningkatan hasil yang sangat baik. Siswa yang tuntas pada posttest sebanyak 19 siswa atau 54,29\%. Pada komponen ini masih banyak siswa yang mendapatkan nilai tidak tuntas yakni sebanyak 16 siswa atau sebesar 45,71\% yang disebabkan karena pada jawaban yang telah dikemukakan oleh subjek kurang tepat dan tidak memenuhi indikator yang telah ditentukan sehingga nilai yang diperoleh untuk posttest rendah. Rata-rata nilai yang diperoleh untuk komponen analisis sebesar 2,79 yang merupakan rata-rata terendah dari komponen keterampilan berpikir kritis lainnya. Namun berdasarkan hasil di atas menunjukkan bahwa keterampilan berpikir kritis siswa dengan komponen analisis meningkat yang dapat dilihat nilai pretest ke nilai posttest. Kendala waktu yang terbatas pada saat pembelajaran juga menjadi penyebab komponen analisis menjadi tidak tersampaikan secara maksimal. Berikut disajikan salah satu hasil posttest subjek pada gambar 4. 


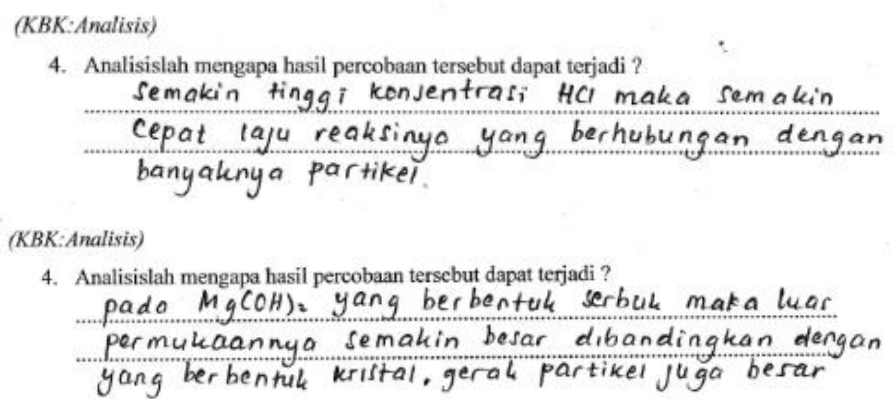

Gambar 4. Hasil Posttest salah satu subjek pada Komponen Analisis

Pada gambar 4, hasil posttest yang dikemukakan sudah semakin baik daripada pretest. Terlihat pada nomor 4 di kedua fenomena menunjukkan jawaban yang sudah tepat sesuai dengan kisi-kisi soal. Aktivitas 9 dari tabel 3, yaitu menganalisis data yang memperoleh persentase waktu sebesar $7,02 \%$ pada pertemuan pertama dan 3,27\% pada pertemuan kedua. Dalam aktivitas ini guru membimbing siswa untuk menjawab analisis mengenai percobaan yang telah dilakukan sebelumnya untuk memperoleh informasi tambahan melalui hasil percobaan yang terdapat pada tabel ataupun grafik. Pada pertemuan kedua pembimbingan dikurangi, sehingga secara mandiri siswa dilatih untuk membuat tabel serta grafik dan memasukkan datanya secara benar. Dalam pembelajaran, kegiatan menganalisa hasil percobaan yang telah diperoleh siswa masih diberi bantuan oleh guru guna memperoleh suatu informasi tambahan yang dapat mendukung penemuannya. Aktivitas ini sesuai dengan keterampilan berpikir kritis yang dilatihkan yakni analisis dimana proses mengidentifikasi hubungan-hubungan inferensial yang dimaksud dan aktual diantara pernyataan-pernyataan, pertanyaan-pertanyaan, konsep-konsep, deskripsideskripsi atau bentuk-bentuk mengekspresikan kepercayaan-kepercayaan, penilaian, pengalamanpengalaman, alasan-alasan, informasi atau opini-opini (Filsaime, 2008). Aktivitas pelatihan keterampilan berpikir kritis komponen analisis juga terlihat pada aktivitas 10 pada penelitian ini. Aktivitas 10 pada pertemuan pertama yaitu mengerjakan soal aplikasi yang memperoleh persentase waktu sebesar 7,02\%. Dalam aktivitas ini siswa berlatih dengan mengerjakan soal yang telah disajikan pada LKS yang berhubungan dengan percobaan yang telah dilakukan dengan bantuan serta bimbingan guru untuk memperoleh informasi tambahan untuk dapat menarik kesimpulan di akhir.

\section{Komponen Inferensi}

Keterampilan berpikir kritis pada komponen inferensi diukur sebanyak 1 soal uraian dimana soal tersebut membahas tentang penarikan kesimpulan berdasarkan fenomena yang telah diberikan. Pada komponen inferensi, jawaban yang dituliskan siswa masih belum benar sehingga masih dikatakan keterampilan berpikir kritis pada komponen ini masih rendah. Pengertian inferensi menurut Facione (dalam Filsaime, 2008) yaitu mengidentifikasi dan memperoleh unsur-unsur yang diperlukan untuk membuat kesimpulan-kesimpulan yang masuk akal; membuat dugaandugaan atau hipotesis; mempertimbangkan informasi yang relevan dan menyimpulkan konsekuensi-konsekuensi dari data, situasi-situasi, pertanyaan-pertanyaan, atau bentuk representasi lainnya. Hasil rata-rata pretest siswa menunjukkan 0,31 atau hampir 100\% siswa tidak tuntas. Berikut disajikan hasil pretest salah satu subjek pada gambar 5. 


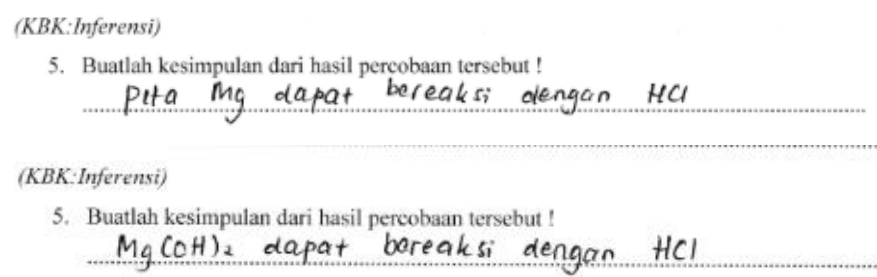

Gambar 5. Hasil Pretest salah satu subjek pada Komponen Inferensi

Pada gambar 5, hasil pretest menujukkan jawaban yang kurang tepat. Pada kedua fenomena jawaban yang dikemukakan tidak menunjukkan adanya pengaruh dari reaksi tersebut. Pada nilai pretest hampir seluruh siswa mendapatkan nilai di bawah KKM, hal ini dikarenakan siswa belum bisa mengkaitkan antara variabel respon dengan varibel manipulasi sehingga jawaban yang didapatkan tidak sesuai dengan indikator penilaian. Masih banyak pula siswa yang kebingungan sehingga tidak sedikit yang memilih untuk tidak menjawab. Ketika pembelajaran berlangsung siswa kemudian diajarkan dan dilatihkan untuk dapat menjawab soal keterampilan berpikir kritis pada komponen inferensi dengan mengerjakan soal yang terdapat LKS sebagai latihan. Setelah pembelajaran siswa lebih mudah mengerjakan soal posttest yang dapat dilihat pada hasil posttest. Hasil nilai dari posttest menjadi sangat baik dan seluruh siswa sebanyak 35 siswa memperoleh nilai di atas KKM yaitu $\geq 2,66$. Hasil rata-rata nilai yang di peroleh siswa sebesar 3,87 atau sebesar 100\% siswa tuntas. Berikut disajikan hasil posttest salah satu subjek pada gambar 6 .

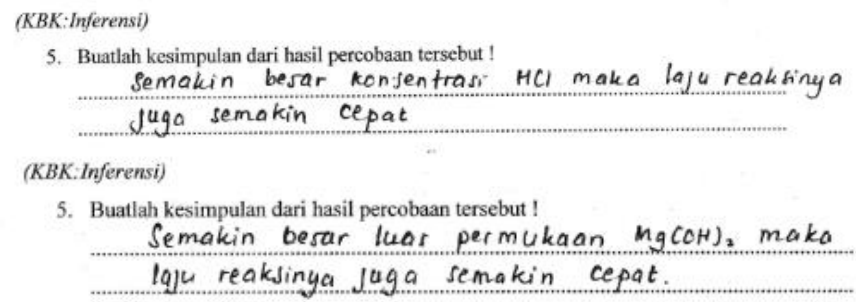

Gambar 6. Hasil Posttest salah satu subjek pada Komponen Inferensi

Pada gambar 6, hasil posttest yang dikemukakan sudah semakin baik daripada pretest. Terlihat pada nomor 5 kedua fenomena menunjukkan jawaban yang sudah tepat sesuai dengan kisi-kisi soal. Pada penyampaiannya komponen ini dilatihkan dengan bagaimana cara membuat hasil akhir berupa kesimpulan dari apa yang telah mereka lakukan dan dapatkan. Dari hasil aktivitas siswa menujukkan bahwa aktivitas dominan yang terjadi pada kegiatan membuat kesimpulan menurun yang sebelumnya mendapatkan angka yang lebih banyak kemudian menjadi lebih sedikit. Hal tersebut menujukkan siswa telah mengerti bagaimana cara mengkaitkan apa yang telah mereka peroleh dengan apa yang telah mereka lakukan di luar dari keterbatasan waktu yang di gunakan pada saat pembelajaran. Hasil tersebut menunjukkan bahwa keterampilan berpikir kritis siswa pada komponen inferensi meningkat dilihat dari nilai pada saat pretest ke nilai posttest.

Aktivitas 3 yaitu merumuskan masalah dan mencatatnya di LKS dengan persentase waktu sebesar 5,66\% pada pertemuan pertama dan 10,25 pada pertemuan kedua. Aktivitas yang dilakukan oleh guru yaitu membimbing siswa untuk merumuskan masalah setelah memperoleh informasi pada fenomena di LKS, memahami informasi yang telah didapatkan kemudian mengubahnya infromasi tersebut ke dalam bentuk pertanyaan. Pada pertemuan pertama rumusan masalah masih diberikan pilihan, dikarenakan pada tahap awal bimbingan perlu diberikan. Namun siswa tetap diminta untuk membaca serta memahami informasi yang didapatkan tersebut untuk memilih secara tepat pilihan rumusan masalah yang diberikan pada LKS. Pada pertemuan kedua proses pembimbingan dikurangi dengan cara menyuruh siswa secara mandiri untuk membuat rumusan masalahnya sendiri berdasarkan fenomena yang telah di berikan. Hal tersebut berdampak pada waktu dominan yang lebih banyak di butuhkan dalam aktivitas 3. Aktivitas di atas sesuai dengan keterampilan berpikir kritis yang di latihkan yaitu inferensi. Pengertian 
inferensi menurut Facione (dalam Filsaime, 2008) yaitu mengidentifikasi dan memperoleh unsurunsur yang diperlukan untuk membuat kesimpulan-kesimpulan yang masuk akal; membuat dugaan-dugaan atau hipotesis; mempertimbangkan informasi yang relevan dan menyimpulkan konsekuensi-konsekuensi dari data, situasi-situasi, pertanyaan-pertanyaan, atau bentuk representasi lainnya. Selain aktivitas 3 terdapat aktivitas yang melatihkan keterampilan berpikir kritis komponen inferensi yakni aktivitas 11. Aktivitas ini yaitu menarik kesimpulan yang memperoleh persentase waktu sebesar 4,07\% pada pertemuan pertama dan 3,27\% pada pertemuan kedua. Dalam aktivitas ini siswa mengumpulkan seluruh informasi yang telah diperoleh mulai awal pembelajaran hingga akhir untuk menarik hasil akhir dari pembelajaran ini yaitu berupa suatu kesimpulan. Pada kegiatan ini waktu dominan yang dibutuhkan berkurang pada pertemuan kedua, hal ini disebabkan siswa telah terlatih untuk menarik kesimpulan berdasarkan hipotesis yang telah mereka buat dan berdasarkan hasil percobaannya.

\section{Komponen Eksplanasi}

Pada soal pretest dan posttest keterampilan berpikir kritis komponen eksplanasi terdapat satu buah soal uraian yang berisi tentang pengaruh faktor-faktor yang mempengaruhi laju reaksi dengan teori yang telah diperoleh siswa sebelumnya. Keterampilan berpikir kritis pada komponen eksplanasi diukur sebanyak 1 soal uraian dimana soal tersebut membahas tentang kesimpulan yang telah siswa dapat dengan teori yang telah didapatkan oleh siswa. Pengertian eksplanasi menurut Facione (dalam Filsaime, 2008) yaitu mampu menyatakan hasil-hasil dari penalaran seseorang menjustifikasi penalaran tersebut dari sisi pertimbangan-pertimbangan evidensial, konseptual, metodologis dan kontekstual dimana hasil-hasil seseorang tersebut berdasar, dan mempresentasikan penalaran seseorang dalam bentuk argumen-argumen yang kuat. Pada nilai pretest hampir seluruh siswa memperoleh nilai di bawah KKM yaitu $\leq 2,66$ dengan nilai rata-rata hanya sebesar 0,11. Hal ini disebabkan siswa masih belum bisa menghubungkan antara teori yang telah mereka dapatkan sebelumnya dengan teori yang baru mereka dapatkan, hal tersebut dibuktikan dengan masih banyaknya siswa yang menjawab tidak sesuai indikator yang telah ditentukan. Tidak banyak pula siswa yang tidak menjawab dikarenakan kebingungan untuk menjawab. Berikut disajikan hasil pretest salah satu subjek pada gambar 7.

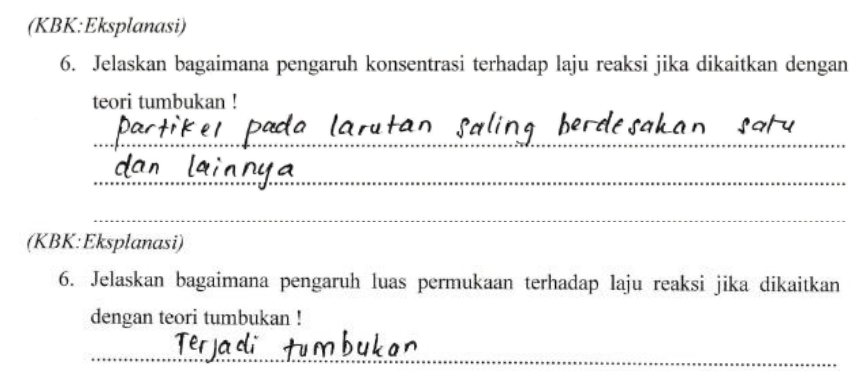

Gambar 7. Hasil Pretest salah satu subjek pada Komponen Eksplanasi

Pada gambar 7, jawaban pretest yang di kemukakan kurang tepat. Jawaban yang di jawab kurang menunjukkan keterkaitan antara fenomena dan informasi yang telah diperoleh sebelumnya. Pada fenomena konsentrasi tidak ada keterkaitannya dengan pertanyaan begitu pula pada fenomena luas permukaan. Pada saat posttest siswa dapat dengan mudah menyelesaikan soal yang disajikan yakni soal keterampilan berpikir kritis dengan komponen eksplanasi. Hal ini dibuktikan dengan hasil nilai dari posttest yang sangat baik dan sebanyak 33 siswa atau 94,28\% mendapatkan nilai di atas KKM yakni 2,66 sedangkan 1 siswa atau 5,72\% mendapatkan nilai masih di bawah KKM yakni 2,66 dengan nilai rata-rata pada komponen ini untuk posttest sebesar 3,60. Berikut disajikan hasil posttest salah satu subjek pada gambar 8 . 


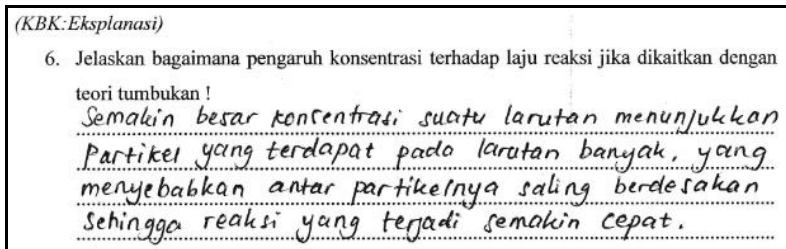

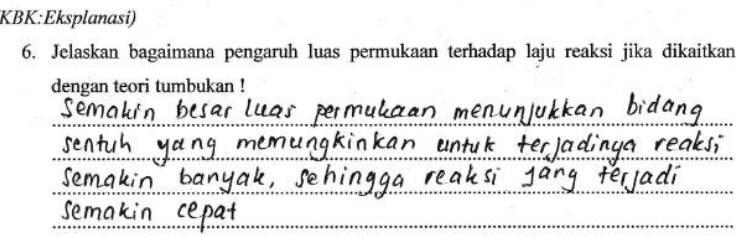

6. Jelaskan bagaimana pengaruh luas permukaan terhadap laju reaksi jika dikaitkan dengan teori tumbukan!

Semakin besar luas permukaan menunjukkan bidang

sentuh yang memungkinkan untuk terjadinga reaks;

semakin banyak, sehingga reaksi jang terjadi

semakin cepat

Gambar 8. Hasil Posttest salah satu subjek pada Komponen Eksplanasi

Pada gambar 8, hasil posttest yang di kemukakan sudah semakin baik daripada pretest. Terlihat pada nomor 6 kedua fenomena menunjukkan jawaban yang sudah tepat sesuai dengan kisi-kisi soal. Hasil tersebut menunjukkan bahwa keterampilan berpikir kritis siswa pada komponen inferensi meningkat dengan dibuktikan hasil nilai pretest ke nilai posttest. Aktivitas 12 yaitu mempresentasikan hasil percobaan, aktivitas ini memperoleh persentase waktu sebesar 11,47\% pada pertemuan pertama dan 7,26\% pada pertemuan kedua. Dalam aktivitas ini guru berperan membimbing yang bertindak sebagai moderator antara kelompok yang menampilkan hasilnya dengan kelompok yang tidak menampilkan hasilnya sehingga apabila terdapat sesuatu hal yang keliru atau berbeda dari materi yang diajarkan guru akan segera untuk meluruskannya. Selain itu pengertian eksplanasi menurut Facione (dalam Filsaime, 2008) yaitu mampu menyatakan hasilhasil dari penalaran seseorang menjustifikasi penalaran tersebut dari sisi pertimbanganpertimbangan evidensial, konseptual, metodologis dan konstekstual dimana hasil-hasil seseorang tersebut berdasar, dan mempresentasikan penalaran seseorang dalam bentuk argumen-argumen yang kuat.

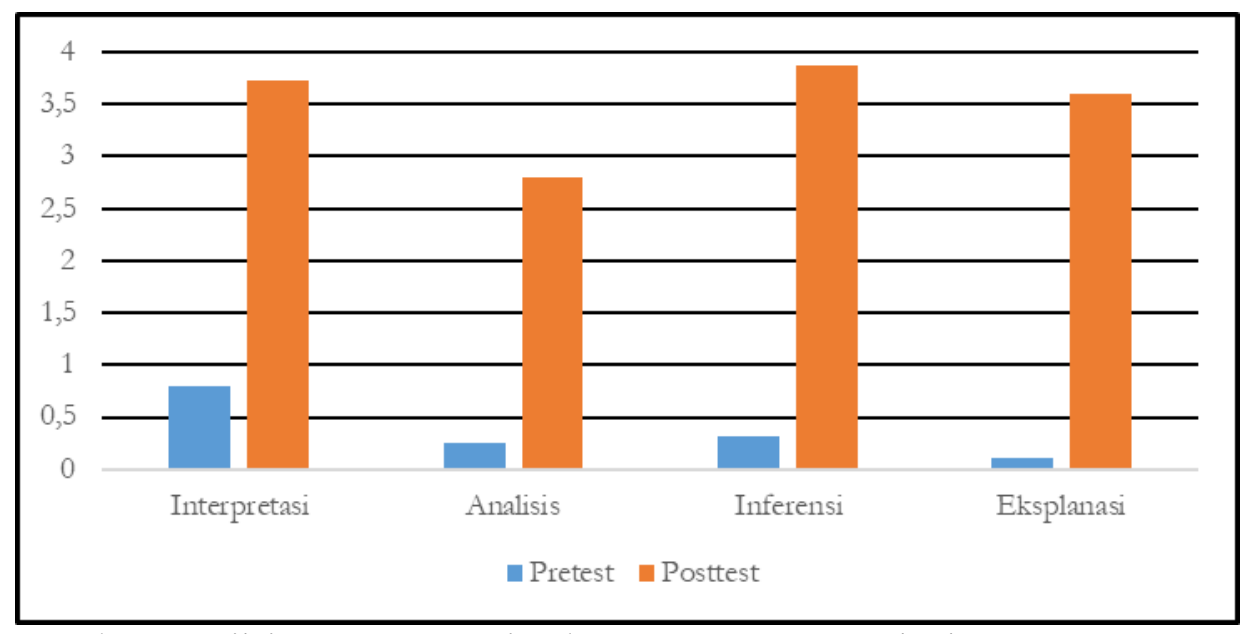

Gambar 9. Nilai pretest-posttest tiap komponen KBK pada dua pertemuan.

\section{KESIMPULAN}

Hasil penelitian in menunjukan bahwa keterampilan yang dilatihkan kepada siswa diukur dengan menggunakan lembar tes keterampilan berpikir kritis pada materi pokok laju reaksi selama dua pertemuan yaitu pada komponen interpretasi sebanyak 97,14\% memperoleh nilai tuntas. Pada komponen analisis 54,29\% siswa memperoleh nilai tuntas. Pada komponen inferensi sebanyak 100\% memperoleh nilai tuntas. Pada komponen eksplanasi sebanyak 94,28\% mendapatkan nilai tuntas. Keterampilan berhasil dilatihkan dengan peningkatan ketuntasan siswa dari pretest ke posttest. Disamping itu, siswa yang melakukan aktivitas relevan selama kegiatan pembelajaran dengan Penerapan Model Pembelajaran Guided Inquiry dengan pendekatan Nested untuk Meningkatkan Keterampilan Berpikir Kritis pada Materi Laju Reaksi mendapat persentase sebesar 97,34\% pada pertemuan 1 dan 98,55\% pada pertemuan 2. Sedangkan aktivitas tidak relevan mendapatkan persentase sebesar 2,66\% pada pertemuan 1 dan $1,45 \%$ pada pertemuan 2 . 
Dapat disimpulkan bahwa aktivitas siswa dikatakan terlaksana dengan baik dan mendukung keefektifan model pembelajaran Guided Inquiry dengan pendekatan Nested dalam meningkatkan keterampilan berpikir kritis.

Disarankan bahwa Keterampilan berpikir kritis komponen analisis mendapat rata-rata nilai posttest yang rendah dibandingkan komponen lainnya, selanjutnya perlu proses membimbing siswa dalam mengerjakan soal analisis sehingga nilai yang didapatkan maksimal. Disamping itu, soal pretest dan posttest perlu dibuat berbeda sehingga data yang diperoleh tidak semu.

\section{DAFTAR RUJUKAN}

Arends, Richard L. 2012. Learning to Teach. New York: Mc Graw Hill.

Asni dan Novita, Dian. 2015. Penerapan Model Pembelajaran Inkuiri Terbimbing Untuk Meningkatkan Keterampilan Proses Siswa Pada Materi Laju Reaksi. UNES A Journal of Chemical Education, 4(1):11-17

Carisma, Adelia Medah dan Novita, Dian. 2017. Penerapan Model Pembelajaran Berbasis Masalah Untuk Melatihkan Keterampilan Berpikir Kritis Pada Materi Pokok Laju Reaksi Kelas XI di SMA Negeri 1 Manyar Gresik. UNESA Journal of Chemical Education. 6(1): 111-117.

Filsaime, Dennis K. 2008. Menguak Rahasia Berpikir Kritis dan Kreatif. Jakarta: Prestasi Pustaka.

Fogarty, Robin. 1991. The Mindful School: How to Integrate the Curricula. Palatine: IRI/Skylight Publishing. Gulo, W. 2002. Strategi Belajar Mengajar. Jakarta: PT. Grasindo.

Hake, R.R. 1998. Interactive-engagement Versus Traditional Methods: A Six-Thousand-Student Survey of Mechanics Test Data for Introductory Physic Courses. Am. J. Phys. 66: 66-74.

Mulyasa. 2011. Menjadi Guru Profesional. Bandung: PT. Remaja Rosdakarya.

Peraturan Departemen Pendidikan Nasional Tahun 2006 tentang Standar Isi SMA/MA.

Peraturan Menteri Pendidikan dan Kebudayaan Republik Indonesia Nomor 70 Tahun 2013 tentang Kerangka Dasar dan Struktur Kurikulum Sekolah Menengah Kejuruan/Madrasah Aliyah Kejuruan.

Peraturan Menteri Nomor 23 tahun 2006 tentang Tujuan Standar Kompetensi Lulusan Satuan Pendidikan (SKL-SP) untuk Pendidikan Menengah.

Riduwan. 2011. Skala Pengukuran Variabel-variabel Penelitian. Bandung: Alfabeta.

Undang-undang Republik Indonesia Nomor 20 Tahun 2003 tentang Sistem Pendidikan Nasional 